Pak. j. sci. ind. res. Ser. B: biol. sci. 2020 63B(2) 71-76

\title{
Effect of Different Operational Parameters on Bio-degradation of Chicken Feathers by Aspergillus niger: Investigation Under Submerged Fermentation Process
}

\author{
Faisal Javeed $^{\text {ab* }}$, Memuna Ghafoor Shahid ${ }^{\mathrm{b}}$ and Ali Javed \\ ${ }^{a}$ Department of Botany, University of the Punjab, Lahore-54590, Pakistan \\ ${ }^{b}$ Department of Botany, Government College University, Lahore-54000, Pakistan \\ 'Institute of Industrial Biotechnology, Government College University, Lahore-54000, Pakistan
}

(received January 18, 2016; revised October 15, 2018; accepted October 22, 2018)

\begin{abstract}
Fungal strain, Aspergillus niger (ATCC 1015) has ability to grow on keratinous material therefore, it was selected for the investigating bio-degradation of chicken feathers. Different operational parameters were studied under submerged fermentation process i.e. effect of substrate concentration, effect of $\mathrm{pH}$, effect of incubation temperature, effect of yeast extract concentration and effect of volume of fermentation medium. A. niger was grown on solid medium of malt extract and agar, due to its ability of rapid growth on it. Complete bio-degradation of the substrate was achieved after 5 days $(0.70 \pm 0.03 \mathrm{U} / \mathrm{mL})$ under standard optimized conditions. Investigation of different operational parameters on bio-degradation of chicken feathers revealed, maximum keratinolytic was observed at $40{ }^{\circ} \mathrm{C}$ incubation temperature, at $0.5 \mathrm{~g} / 100 \mathrm{~mL}$ of substrate concentration, $8 \mathrm{~g} / 100 \mathrm{~mL}$ concentration of yeast extract, at $7 \mathrm{pH}$ of the fermentation medium and at $50 \mathrm{~mL}$ volume of fermentation medium. The present study suggests that $A$. niger could prove to be a potential candidate for production of keratinase and bio-degradation of chicken feathers.
\end{abstract}

Keywords: Aspergillus niger, keratinase, bio-degradation, submerged fermentation, chicken feathers, operational parameters

\section{Introduction}

In recent years, poultry industry has expanded a lot due to massive increase in world population, which in turn has enhanced the demand of poultry products. Subsequently problematic waste production from the poultry industry has been amplified too (Brandelli et al., 2015; Williams et al., 1991). The recent outbreak of bird flu caused by $\mathrm{H} 5 \mathrm{~N} 1$ virus was also due to waste feathers that pollute our environment (Saber et al., 2009). The accumulated waste of chicken feathers creates potential environmental issues because of their resistant nature (Anitha and Palanivelu, 2013).

The bio-technological bio-degradation of agro-industrial waste, especially chicken feathers have numerous advantages including, cost effectiveness, preservation of essential amino acids, utilization for animal feed and fertilizer production as well as it's an environmentally friendly approach. Instead of chemical processing which produces several harmful waste effluents, loss of nutrients, less useful for further utilization of by products (Mazotto et al., 2013; Deivasigamani and Alagappan, 2008; Riffel et al., 2003; Bressollier et al., 1999).

*Author for correspondence; E-mail: javeedfaisal@yahoo.com
Feathers are mainly composed of keratin, which is a highly stable protein. Keratinous material is water insoluble and extremely resistant to degradation (Matikeviciene et al., 2009). Keratinase enzyme is able to hydrolyse keratin and release the free amino acids from keratinous proteins (Shih, 1993). Fungi can readily degrade keratinous substances like chicken feathers by secreting large amount of extracellular keratinase into the culture medium (Anbu et al., 2008). Aspergillus spp. are identified as keratinolytic fungi through number of researches done till present (Brandelli et al., 2015; Saber et al., 2009; Kim, 2003).

The objective of the present study was to investigate the production of keratinase enzyme and bio-degradation of the chicken feathers in submerged fermentation process, by a keratinolytic strain of $A$. niger (ATCC 1015). Data was processed in MS Excel $2013^{\mathrm{TM}}$ to make box plots and statistical analysis of different treatment units. A one way analysis of variance (ANOVA) and F distribution $(\mathrm{p} \leq 0.05)$ was conducted to compare results.

\section{Materials and Methods}

Preparation of substrate. Chicken feathers were collected from local poultry waste site and used as 
substrate for production of keratinase for bio-degradation through A. niger. Attached meat and flesh were removed from the feathers and washed thoroughly, then dried in hot air oven at $50{ }^{\circ} \mathrm{C}$ for $30 \mathrm{~min}$ and were cut into tiny fragments. The fragments were sterilized for further experimentation.

Preparation of inoculum. The fungal strain of $A$. niger (Strain ATCC 1015), was taken from the Institute of Industrial Biotechnology, G.C. University Lahore.

The strains were cultivated on solid medium consisting of agar and malt extract $(2 \mathrm{~g} / 100 \mathrm{~mL}$ each). The slant cultures were incubated at $28{ }^{\circ} \mathrm{C}$ for $96-120 \mathrm{~h}$ until maximum growth was achieved. Sub-culturing was carried out after every 2 weeks and frequently examined under a light microscope to avoid any contamination.

For the preparation of $50 \mathrm{~mL}$ of inoculum, $40 \mathrm{~mL}$ of distilled water was taken in $250 \mathrm{~mL}$ Erlenmeyer flask containing chicken feathers $(0.2 \mathrm{~g} / 50 \mathrm{~mL})$, yeast extract and peptone $(1 \mathrm{~g} / 50 \mathrm{~mL}$ each $), \mathrm{ZnSO}_{4}, \mathrm{MgSO}_{4}$ and $\mathrm{FeSO}_{4}(0.05 \mathrm{~g} / 100 \mathrm{~mL}$ each $)$ and autoclaved at $121^{\circ} \mathrm{C}$, $15 \mathrm{lb} / \mathrm{inch}^{2}$ for $15 \mathrm{~min} .10 \mathrm{~mL}$ of sterilized distilled water was added in the slant and spores were suspended in the solution. The $\mathrm{pH}$ of the medium was maintained at 7, with the help of $1 \mathrm{~N} \mathrm{HCl}$ and $1 \mathrm{~N} \mathrm{NaOH}$ solutions. The flask was kept in a shaking incubator rotating at $120 \mathrm{rpm}$ at $28^{\circ} \mathrm{C}$ for $96 \mathrm{~h}$.

Submerged fermentation. The fermentation medium was prepared by adding chicken feathers $(0.2 \mathrm{~g})$ along with yeast extract and peptone $(2 \mathrm{~g} / 100 \mathrm{~mL}$ each), $\mathrm{K}_{2} \mathrm{HPO}_{4}(0.2 \mathrm{~g} / 100 \mathrm{~mL})$ and $\mathrm{ZnSO}_{4}, \mathrm{MgSO}_{4}, \mathrm{FeSO}_{4}$ $(0.1 \mathrm{~g} / 100 \mathrm{~mL}$ each) and were dissolved in $90 \mathrm{~mL}$ distilled water and then sterilized, then $10 \mathrm{~mL}$ of the inoculum was added in the flask and the $\mathrm{pH}$ of the medium was maintained at 7 , with the help of $1 \mathrm{~N} \mathrm{HCl}$ and $\mathrm{NaOH}$ solutions. The flask was then kept in the shaking incubator rotating at $120 \mathrm{rpm}$ at the temperature of $28^{\circ} \mathrm{C}$ for $120 \mathrm{~h}$. Since the enzyme is extracellular, it was extracted by centrifugation of the mixture followed by weighing the cell biomass.

Keratinolytic assay. Crude enzyme extracted as described in section 2.3, was used to evaluate enzyme activity. Protein content was determined using modified method of Mazotto et al. (2013) using tyrosine as standard. One Unit of keratinolytic activity was defined as the amount of enzyme required to release $1 \mu \mathrm{g}$ of tyrosine per $\mathrm{mL}$ under experimental condition.
Keratinase activity was determined according to the modified Anson's method (Anson, 1938). $1.0 \mathrm{~mL}$ of the culture broth was taken in a $100 \mathrm{~mL}$ flask and 1.0 $\mathrm{mL}$ of $\mathrm{pH} 7.0$ phosphate buffer was added in it. $1 \mathrm{~mL}$ of the substrate ( $2 \%$ tyrosine $\mathrm{pH} 7.0)$ was added in the buffer enzyme solution and incubated at $37^{\circ} \mathrm{C}$ for 10 min in a water bath, then $10 \mathrm{~mL}$ of $5 \mathrm{~N}$ TCA (Tri-chloro acetic acid) was added to stop the reaction. The precipitated keratin was then filtered off and $5 \mathrm{~mL}$ of the filtrate was taken in a test tube. Then $10.0 \mathrm{~mL}$ of $0.5 \mathrm{~N} \mathrm{Na}_{2} \mathrm{CO}_{3}$ solution and $3.0 \mathrm{~mL}$ of the Folin-Ciocalteu reagent were added in the filtrate. Final readings were taken with spectrophotometer at $550 \mathrm{~nm}$. Blanks of the samples were prepared by adding the TCA before the addition of substrate.

Effect of different operational parameters on keratinolytic activity. Effect of different concentrations of substrate. For evaluating the effect of different concentrations of substrate on keratinolytic activity, concentrations ranging from $0.2-0.7 \mathrm{~g} / 100 \mathrm{~mL}$ of fermentation medium were used for the biodegradation by $A$. niger. The $\mathrm{pH}$ of the medium was maintained at 7.0 and incubated at $28{ }^{\circ} \mathrm{C}$ for $96 \mathrm{~h}$.

Effect of different pH. For investigating the effect of different $\mathrm{pH}$ on the bio-degradation of chicken feathers by $A$. niger, the fermentation medium was exposed to various $\mathrm{pH}$ at 5, 6,7 and 8 . The medium was incubated at $28{ }^{\circ} \mathrm{C}$ for $96 \mathrm{~h}$ and using $0.5 \mathrm{~g}$ chicken feathers as substrate in each flask.

Effect of incubation temperature. To determine the effect of different incubation temperatures on the biodegradation of chicken feathers by $A$. niger, the fermentation medium was incubated at various temperatures i.e. $20,30,40$ and $50{ }^{\circ} \mathrm{C}$. The medium was incubated at $7 \mathrm{pH}$ for $96 \mathrm{~h}$ and using $0.5 \mathrm{~g}$ chicken feathers.

Effect of different concentrations of yeast extract. To study the effect of different concentrations of yeast extracts on the bio-degradation of chicken feathers by A. niger, different concentrations of yeast extract $(2 \mathrm{~g}$, $4 \mathrm{~g}, 6 \mathrm{~g}$ and $8 \mathrm{~g} / 100 \mathrm{~mL}$ ) were added in the fermentation medium. The medium was incubated at $28{ }^{\circ} \mathrm{C}$ for $96 \mathrm{~h}$, using $0.5 \mathrm{~g}$ chicken feathers and $\mathrm{pH}$ was maintained at 7 .

Effect of different volumes of fermentation media. For the evaluation of the effect of fermentation volume on enzyme production, various volumes of fermentation media were prepared ranging from; $50 \mathrm{~mL}, 100 \mathrm{~mL}$, 
$150 \mathrm{~mL}$ and $200 \mathrm{~mL}$, the $\mathrm{pH}$ was maintained at 7 and $0.5 \mathrm{~g}$ of chicken feathers were added as substrate in each flask. The media were incubated at $28{ }^{\circ} \mathrm{C}$ for 96 $\mathrm{h}$ for the determination of its effect on biodegradation of chicken feathers.

Statistical analysis. All the experiments were performed in triplicates and results were expressed as mean \pm Standard deviation. The data was statistically analysed by ANOVA (analysis of variance) considering $p<0.05$ as significant difference. Data was processed in MS Excel $2013^{\mathrm{TM}}$ to make box plots and statistical analysis of different treatment units. A one-way analysis of variance (ANOVA) and $\mathrm{F}$ distribution $(\mathrm{p} \leq 0.05)$ was conducted to compare results.

\section{Results and Discussion}

Keratinolytic activity. This study was performed to evaluate the bio-degradation of chicken feathers and production of keratinase by $A$. niger under submerged fermentation process and to evaluate optimum levels pf different operational parameters for keratinolytic activity. The strain (ATCC 1015) of A. niger was able to successfully bio-degraded chicken feathers by submerged fermentation process as sole source of carbon. Keratinase enzyme was produced and chicken feathers were successfully bio-degraded within five days of submerged fermentation process (Table 1). It was previously observed that $A$. niger is a keratinolytic fungus and has the ability to produce extracellular enzyme kertinase.

Table 1. Bio-degradation of Chicken feathers by Aspergillus niger

\begin{tabular}{|c|c|c|c|c|}
\hline $\begin{array}{l}\text { Substrate } \\
\text { concen- } \\
\text { tration }(\mathrm{g})\end{array}$ & $\begin{array}{l}\text { Specific } \\
(\mathrm{U} / \mathrm{mL})\end{array}$ & & $\begin{array}{l}\text { Mean } \\
\text { value }\end{array}$ & $\begin{array}{l}\text { Weight of cel } \\
\text { biomass after } \\
\text { fermentation } \\
\text { (g) }\end{array}$ \\
\hline 0.50 & $0.60 \quad 0.72$ & 0.79 & 0.68 & 0.39 \\
\hline
\end{tabular}

The present work showed that $0.5 \mathrm{~g} / 100 \mathrm{~mL}$ concentration of substrate, $\mathrm{pH} 7$ of the fermentation medium, $50 \mathrm{~mL}$ volume of fermentation medium, $40{ }^{\circ} \mathrm{C}$ incubation temperature and $8 \mathrm{~g} / 100 \mathrm{~mL}$ concentration of yeast extract were optimal conditions for the maximum biodegradation of chicken feathers and production of enzyme by $A$. niger, elaborated below.
Effect of different operational parameters on keratinolytic activity. Effect of different concentrations of substrate. A. niger gave highest production of enzyme $(0.68 \pm 0.05 \mathrm{U} / \mathrm{mL})$ at $0.5 \mathrm{~g}$ of chicken feathers, while lowest production of enzyme $(0.30 \pm 0.03 \mathrm{U} / \mathrm{mL})$ was at $0.7 \mathrm{~g}$ of chicken feathers (Fig. 1).

Effect of different $\boldsymbol{p H}$. A . niger gave highest production of enzyme $(0.60 \pm 0.03 \mathrm{U} / \mathrm{mL})$ at $\mathrm{pH} 7$, while lowest production of enzyme $(0.40 \pm 0.02 \mathrm{U} / \mathrm{mL})$ was at $\mathrm{pH} 8$ (Fig. 2).

Effect of incubation temperature. A. niger gave highest production of enzyme $(0.73 \pm 0.003 \mathrm{U} / \mathrm{mL})$ at $40{ }^{\circ} \mathrm{C}$, while lowest production of enzyme $(0.65 \pm 0.02 \mathrm{U} / \mathrm{mL})$ was at $50^{\circ} \mathrm{C}$ (Fig. 3).

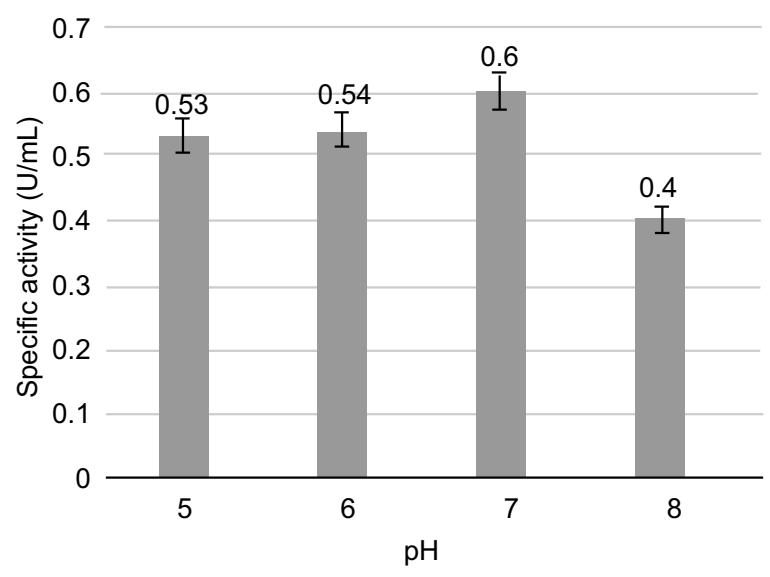

Fig. 1. Effect of substrate concentration on keratinolytic activity.

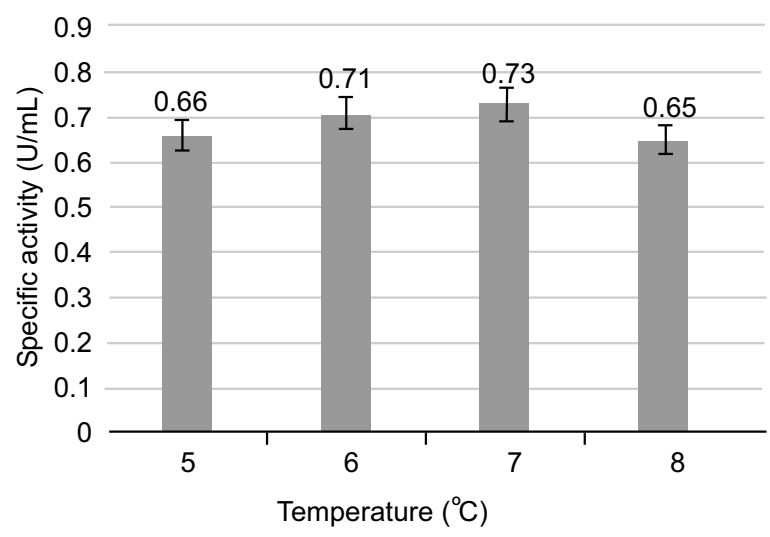

Fig. 2. Effect of $\mathrm{pH}$ on keratinolytic activity. 


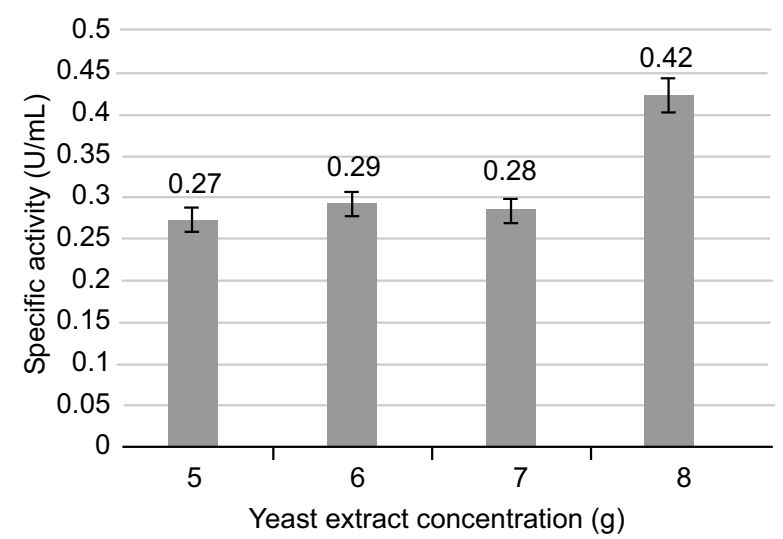

Fig. 3. Effect of temperature on keratinolytic activity.

Effect of different concentrations of yeast extract. $A$. niger gave highest production of enzyme $(0.42 \pm 0.01$ $\mathrm{U} / \mathrm{mL}$ ) at $8 \mathrm{~g}$ of yeast extract, while lowest production of enzyme $(0.27 \pm 0.05 \mathrm{U} / \mathrm{mL})$ was at $4 \mathrm{~g}$ of yeast extract (Fig. 4).

Effect of different volumes of fermentation media. The optimum conditions fermentation volume was 50 $\mathrm{mL}$ of fermentation medium, where highest production of enzyme $(0.42 \pm 0.01 \mathrm{U} / \mathrm{mL})$ was observed, while lowest production of enzyme $(0.27 \pm 0.05 \mathrm{U} / \mathrm{mL})$ was found at $200 \mathrm{~mL}$ of fermentation medium volume (Fig. 5).

The one-way analysis of variance (ANOVA) T-Test compared the measure of effect of different concentrations of substrate, $\mathrm{pH}$, incubation temperature, yeast

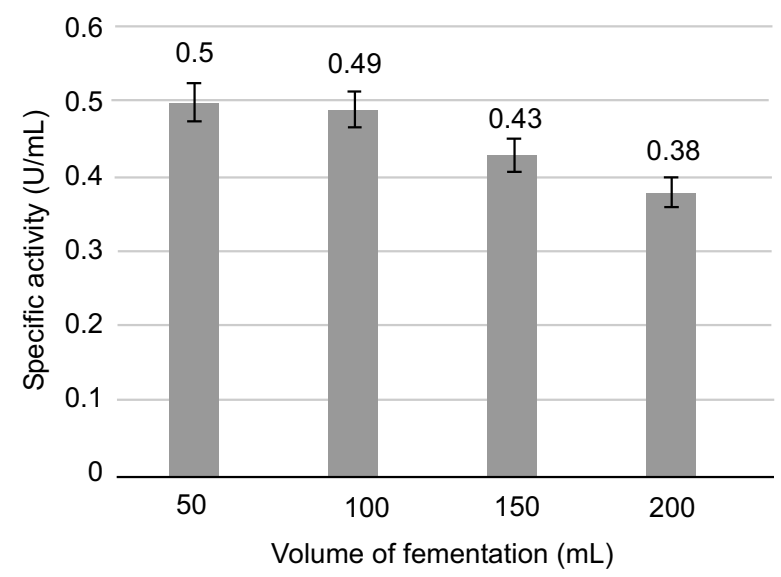

Fig. 4. Effect of yeast extract concentration on keratinolytic activity. extract and fermentation volume on keratinolytic activity, the results were found statistically significant with $\mathrm{F}=15.2, \mathrm{~F}=6.2, \mathrm{~F}=3.5, \mathrm{~F} 3.6$ and 6.0 at a level of $\mathrm{p}=0.05$, respectively.

In this study, we aimed to observe the bio-degradation potential of $A$. niger and production of keratinase, in addition the bio-degradation was subjected to different operational parameters to identify the optimum conditions for maximum bio-degradation of substrate and production of enzyme. We found that $A$. niger strain ATCC 1015 partially degraded the substrate during growth in submerged fermentation medium with feather as the only carbon source. Similar results were described by Mazotto et al. (2013), they isolated 28 mutant species of $A$. niger from poultry waste site, and conducted biodegradation of chicken feathers by submerged as well as solid state fermentation techniques. However, their study showed maximum keratinolytic activity in solid state fermentation as compared to submerged fermentation process. They reported the production of high mass peptidases and their results depict that $A$. niger is a promising candidate for bio-degradation of chicken feathers and production of keratinolytic enzymes. Other studies have also showed that solid state fermentation by Aspergillus spp. and bacterial species produce better results and have ability to produce more quantities of enzymes responsible for bio-degradation of keratin substrates as compared to submerged fermentation process (Belmessikh et al., 2013; Rai et al., 2009; De Azeredo et al., 2006).

The investigation showed that the maximum degradation of chicken feathers was at $40{ }^{\circ} \mathrm{C}$ and minimum at 20 and $50{ }^{\circ} \mathrm{C}$. Saber et al. (2009) showed similar results that keratinolytic activity by Aspergillus spp. was highest at $35^{\circ} \mathrm{C}-40^{\circ} \mathrm{C}$ and least at $20^{\circ} \mathrm{C}$ and $50{ }^{\circ} \mathrm{C}$ temperatures, using chicken feathers as sole source of carbon and nitrogen.

Aspergillus spp. are ubiquitous fungi and are able to grow on natural media without any special requirements. $A$. niger was carefully isolated and was cultured on malt extract and agar medium for the present study. The strain was confirmed by its morphological characteristics under a microscope and was used for biodegradation of chicken feathers in submerged cultivation process. Friedrich et al. (1999) isolated fungi from soil and demonstrated that $A$. niger showed keratinolytic activity using chicken feathers as substrate. Kim (2003) proved that $A$. niger can grow on chicken feather 
substrate as sole source of carbon, and has the ability to degrade keratin, they investigated on five Aspergillus species their study revealed that A. flavus, A. niger and A. terreus showed highest keratinolytic activity. Lopes et al. (2011) used A. niger to degrade chicken feathers in submerged cultivation process and showed that A. niger had high keratinolytic activity.

The production of keratinase enzyme by $A$. niger was maximum at $0.5 \mathrm{~g} / 100 \mathrm{~mL}$ concentration of substrate (chicken feathers) and minimum at $0.7 \mathrm{~g} / 100 \mathrm{~mL}$ of substrate. Similarly, Brandelli and Riffel (2005) estimated that with the increase in substrate concentration there is a slight decrease in keratinase production. The production of keratinase was found to be maximum at $\mathrm{pH}$ 7.0. It was estimated that increase in $\mathrm{pH}$ caused a slight decrease in keratinase production. Saber et al. (2009) also described that highly acidic or alkaline $\mathrm{pH}$ caused reduction in the keratinase production by Aspergillus spp. and 7-7.5 $\mathrm{pH}$ was the most suitable range for maximum keratinase production and biodegradation of the chicken feathers. The production of keratinase enzyme was maximum at $8 \mathrm{~g} / 100 \mathrm{~mL}$ concentration of yeast extract and minimum at $4 \mathrm{~g} / 100$ $\mathrm{mL}$ of substrate. It was found that increase in the yeast extract concentration also increases the keratinase enzyme production. Similar results were found by Mazotto et al. (2010), the keratinolytic activity was enhanced by the addition of yeast extract in the medium. However, they used bacterial species and human hair as kertain substrate. Maximum production of keratinase was found in the $50 \mathrm{~mL}$ fermentation volume, while minimum production of the enzyme was in $200 \mathrm{~mL}$ medium volume. Raju and Divakar (2013) found that by increasing the fermentation medium volume the production of keratinase decreases slightly.

\section{Conclusion}

The results suggest that bio-degradation of chicken feathers by $A$. niger can successfully bio-degrade poultry feathers and thus can help to reduce the agro-industrial waste. Moreover, this procedure can prove to be a helpful process for biotechnological processes and for industrial production of keratinase enzyme that can be used in production of several useful commercial products. Furthermore, this process can be a better alternative than conventional methods of management of waste chicken feathers which are energy consuming, less efficient and not environmentally friendly. Therefore, it is recommended that bio-degradation of discarded chicken feathers by micro-organisms should be adopted because chicken feathers are problematic agro-industrial waste of poultry industry. Moreover, we also encourage to conduct research on other fungal as well as bacterial species and identify optimum conditions for efficient and large scale bio-degradation of waste poultry feathers. For a developing country like Pakistan, bio-degradation of chicken feathers by $A$. niger can be promising candidate, because it is a less energy consuming process, cost effective and has numerous industrial and commercial applications.

Conflict of Interest. The authors declare no conflict of interest.

\section{References}

Anbu, P., Hilda, A., Sur, H.W., Hur, B.K., Jayanthi, S. 2008. Extracellular keratinase from Trichophyton sp. HA-2 isolated from feather dumping soil. International Biodeterioration and Biodegradation. 62: $287-292$

Anitha, T.S., Palanivelu, P. 2013. Molecular identification of two new isolates of keratinolytic fungi using internal transcribed spacer regions. Journal of Applied Sciences in Environmental Sanitation, 8: 67-75.

Anson, M.L. 1938. Plant proteolytic enzyme. Journal of General Physiology, 22: 79-84.

Belmessikh, A., Boukhalfa, H., Mechakra-Maza, A., Gheribi-Aoulmi, Z., Amrane, A. 2013. Statistical optimization of culture medium for neutral protease production by Aspergillus oryzae. Comparative study between solid and submerged fermentations on tomato pomace. Journal of the Taiwan Institute of Chemical Engineers, 44: 377-385.

Brandelli, A., Riffel, A. 2005. Production of an extracellular keratinase from Chryseobacterium sp. growing on raw feathers. Electron. Journal of Biotechnology, 8: 35-42.

Brandelli, A., Sala, L., Kalil, S.J. 2015. Microbial enzymes for bioconversion of poultry waste into added-value products. Food Research International, 73: 3-12.

Bressollier, P., Letourneau, F., Urdaci, M., Verneuil, B. 1999. Purification and characterization of a keratinolytic serine proteinase from Streptomyces albidoflavus. Applied and Environmental Microbiology, 65: 2570-2576.

De Azeredo, L.A.I., De Lima, M.B., Coelho, R.R.R., Freire, D.M.G. 2006. Thermophilic protease 
production by Streptomyces sp. 594 in submerged and solid-state fermentations using feather meal. Journal of Applied Microbiology, 100: 641-647.

Deivasigamani, B., Alagappan, K.M. 2008. Industrial application of keratinase and soluble proteins from feather keratins. Journal of Environmental Biological, 29: 933-936.

Friedrich, J., Gradisar, H., Mandin, D., Chaumont, J.P. 1999. Screening Fungi for synthesis of keratinolytic enzymes. Lett. Applied Microbiology, 28: 127-130.

Kim, J. 2003. Keratinolytic activity of five Aspergillus species isolated from poultry forming soil in Korea. Mycobiology, 31: 157-161.

Lopes, F.C., Dedavid e Silva, L.A., Tichota, D.M., Daroit, D.J., Velho, R.V., Pereira, J.Q., Corrêa, A.P.F., Brandelli, A. 2011. Production of proteolytic enzymes by a keratin-degrading Aspergillus niger. Enzyme Research, 487093.

Matikeviciene, V., Masiliuniene, D., Grigiskis, S. 2009. Degradation of keratin containing wastes by bacteria with keratinolytic activity. Environment Technology Resources, 1: 284-289.

Mazotto, A.M., Cedrola, S.M., Lins, U., Rosado, A.S., Silva, K.T., Chaves, J.Q. Rabinovitch, L., Zingali, R.B., Vermelho, A.B. 2010. Keratinolytic activity of Bacillus subtilis AMR using human hair. Lett. Applied Microbiology, 50: 89-96.

Mazotto, A.M., Couri, S., Damaso, M.C., Vermelho, A.B. 2013. Degradation of feather waste by Aspergillus niger keratinases: Comparison of submerged and solid-state fermentation. International Biodeterioration and Biodegradation, 85: 189-195.

Rai, S.K., Konwarh, R., Mukherjee, A.K. 2009. Purification, characterization and biotechnological application of an alkaline b-keratinase produced by Bacillus subtilis RM-01 in solid-state fermentation using chicken-feather as substrate. Biochemical Engineering Journal, 45: 218-225.

Raju, E.V.N., Divakar, G. 2013. Production of keratinase by using pseudomonas aeruginosa isolated from poultry waste. International Journal of Pharmaceutical, Chemical and Biological Sciences, 3: 79-86.

Riffel, A., Brandelli, A., Heeb, P., Lucas, F. 2003. Characterization of a new keratinolytic bacterium that completely degrades native feather keratin. Arch. Microbial, 179: 258-265.

Saber, W.I.A., El-Metwally, M.M., El-Hersh, M.S. 2009. Keratinase production and biodegradation of some keratinous waste by Alternaria tenuissima and Aspergillus nidulans. Research Journal of Microbiology, 5: 21-35.

Shih, J.C.H. 1993. Recent Development in Poultry Waste Digestion and Feather Utilization. Poultry Science, 72: 1617-1620.

Williams, C.M., Lee, C.G., Garlich, J.D., Shih, J.C.H. 1991. Evolution of bacterial feather fermentation product, feather lyaste, as a feed protein. Poultry Science, 70: 85-94. 